\title{
Adapting a Neural Engineering Summer Camp for High School Students to a Fully Online Experience
}

\author{
Kristen Clapper Bergsman ${ }^{1}$ and Eric H. Chudler (i) ${ }^{1,2}$ \\ ${ }^{1}$ Center for Neurotechnology, University of Washington, Seattle, WA, USA; and ${ }^{2}$ Department of Bioengineering, University of \\ Washington, Seattle, WA, USA
}

(Received 22 June 2020; accepted 23 July 2020; published online 17 August 2020)

\begin{abstract}
The COVID-19 pandemic and its resulting health and safety concerns caused the cancellation of many engineering education opportunities for high school students. To expose high school students to the field of neural engineering and encourage them to pursue academic pathways in biomedical engineering, the Center for Neurotechnology (CNT) at the University of Washington converted an inperson summer camp to a fully online program (Virtual REACH Program, VRP) offering both synchronous and asynchronous resources. The VRP is a five-day online program that focuses on a different daily theme (neuroscience, brain-computer interfaces, electrical stimulation, neuroethics, career/academic pathways). Each day, the VRP starts with a live videoconference meeting (lecture and interactive discussion) with a CNT faculty member. The online lectures are supported by at-home learning resources (e.g., text, videos, activities, quizzes) embedded within a digital book created using the Pressbook platform. An online bulletin board (Padlet) is also used by students to share artifacts and build community. Program evaluation will be conducted by an external evaluator. A summative survey will collect information on participants' experiences in the VRP and will help inform future iterations of the program. Although significant time was required to create a digital book, the VRP will reach a larger audience than the prior inperson program and resulted in the creation of learning tools that can be used in the future.
\end{abstract}

Keywords-Remote learning, K-12, Summer camp, Neural engineering, Neuroscience.

Address correspondence to Eric H. Chudler, Center for Neurotechnology, University of Washington, Seattle, WA, USA. Electronic mail: chudler@uw.edu

\section{CHALLENGE STATEMENT}

Like many other engineering education programs across the country, the Center for Neurotechnology at the University of Washington struggled during Spring 2020 to decide whether to cancel, continue with, or adapt a university-based, in-person summer camp program for high school students, without knowing how the COVID-19 pandemic would affect state, local, and university policies. We ultimately cancelled several of our summer research experience programs for undergraduate and pre-college students because inperson laboratory research with guests was not going to be feasible on our university's campus. However, we felt that a new online program could provide high school students with a learning community centered on their interests in neuroscience, neural engineering, and neurotechnologies. Therefore, we cancelled our Young Scholars Program-REACH, a five day, fee-based, inperson summer camp program, and created something different: the Virtual REACH Program (VRP), a fully online, free program offering both synchronous (live presentations and office hours) and asynchronous (videos, readings, and activities) elements for at-home learning to be held over a five day period during July 2020.

The original, in-person program, Young Scholars Program-REACH, was a fee-based, revenue-generating program for high school students that had been offered over the prior three summers. The program model included two five-day sessions for 25 students per session. Participants received an introduction to the topics of neuroscience, neural engineering, and neuroethics by attending presentations by faculty 
TABLE 1. Virtual REACH program components.

\begin{tabular}{|c|c|c|c|}
\hline Daily theme & Synchronous elements & Asynchronous elements & Community building \\
\hline $\begin{array}{l}\text { Day One: Basics } \\
\text { of Neuro- } \\
\text { science and } \\
\text { Neural Engi- } \\
\text { neering }\end{array}$ & $\begin{array}{l}\text { Zoom: Live presentation on introduction } \\
\text { to neuroscience and neural engi- } \\
\text { neering and office hours with Dr. Eric } \\
\text { Chudler, a neuroscientist. Approxi- } \\
\text { mately } 90 \text { min }\end{array}$ & $\begin{array}{l}\text { Pressbook: Basics of the nervous sys- } \\
\text { tem and neuroanatomy through text, } \\
\text { diagrams, and quiz; } 28 \text { min video on } \\
\text { neurotransmission models; introduc- } \\
\text { tion to neural engineering text }\end{array}$ & $\begin{array}{l}\text { Padlet: Participants are challenged } \\
\text { to build a model of a neuron using } \\
\text { household items and post photos } \\
\text { of their neuron to the daily Padlet }\end{array}$ \\
\hline $\begin{array}{l}\text { Day Two: Brain- } \\
\text { Computer } \\
\text { Interfaces } \\
\text { (BCls) }\end{array}$ & $\begin{array}{l}\text { Zoom: Live presentation on brain-com- } \\
\text { puter interfaces and office hours with } \\
\text { Dr. Rajesh Rao, Department of Elec- } \\
\text { trical and Computer Science. } \\
\text { Approximately } 90 \text { min }\end{array}$ & $\begin{array}{l}\text { Pressbook: Introduction to brain-com- } \\
\text { puter interfaces (BCls) and biosignals } \\
\text { through text, diagrams, and external } \\
\text { articles; } 27 \text { min video; research spot- } \\
\text { light featuring a } 3 \text { min radio story and } \\
\text { article on prosthetic limb advances; } \\
\text { links to external resources for learn- } \\
\text { ing about neuroprosthetics, cochlear } \\
\text { implants, and retinal implants; two } \\
\text { quizzes }\end{array}$ & $\begin{array}{l}\text { Padlet: Participants share their } \\
\text { thoughts about possible chal- } \\
\text { lenges associated with connect- } \\
\text { ing the human brain with } \\
\text { technology in the daily Padlet. } \\
\text { Responses shared with presen- } \\
\text { ter in advance of morning session }\end{array}$ \\
\hline $\begin{array}{l}\text { Day Three: } \\
\text { Brain and } \\
\text { Spinal Cord } \\
\text { Stimulation }\end{array}$ & $\begin{array}{l}\text { Zoom: Live presentation on neurostim- } \\
\text { ulation research and office hours with } \\
\text { Dr. Chet Moritz, Department of } \\
\text { Rehabilitation Medicine. Approxi- } \\
\text { mately } 90 \text { min }\end{array}$ & $\begin{array}{l}\text { Pressbook: History of neurostimulation } \\
\text { and introduction to neurostimulation } \\
\text { techniques through text and dia- } \\
\text { grams; research spotlight featuring a } \\
3 \text { min news video and two articles on } \\
\text { advances in spinal cord rehabilitation; } \\
\text { introduction to deep brain stimulation; } \\
\text { optional resources for further learning }\end{array}$ & $\begin{array}{l}\text { Padlet: Participants share the } \\
\text { questions they have for Dr. Moritz } \\
\text { and his team about their research } \\
\text { on neurostimulation for spinal } \\
\text { cord rehabilitation. Responses } \\
\text { shared with presenter in advance } \\
\text { of morning session }\end{array}$ \\
\hline $\begin{array}{l}\text { Day Four: Neu- } \\
\text { roethics }\end{array}$ & $\begin{array}{l}\text { Zoom: Live presentation on neuroethics } \\
\text { and office hours with Mr. Ishan Das- } \\
\text { gupta, Department of Philosophy. } \\
\text { Approximately } 90 \text { min }\end{array}$ & $\begin{array}{l}\text { Pressbook: Introduction to ethics, } \\
\text { bioethics, and neuroethics through } \\
\text { text and graphics; } 2 \text { min video on } \\
\text { neuroethical issues; } 19 \text { min video on } \\
\text { neuroethical concerns; research } \\
\text { spotlight featuring two articles } \\
\text { describing neuroethics research pro- } \\
\text { jects; four quizzes; optional resources } \\
\text { for further learning }\end{array}$ & $\begin{array}{l}\text { Padlet: Participants share a key } \\
\text { take-away from their exploration } \\
\text { of resources related to a major } \\
\text { area of neuroethical concern: } \\
\text { privacy and consent, agency and } \\
\text { identity, augmentation, or bias } \\
\text { Responses shared with presenter in } \\
\text { advance of morning session }\end{array}$ \\
\hline $\begin{array}{l}\text { Day Five: Col- } \\
\text { lege and Ca- } \\
\text { reer Pathways }\end{array}$ & $\begin{array}{l}\text { Zoom: Live presentation on college } \\
\text { preparation and office hours with } \\
\text { Mr. Dave Wolczyk, Math Science } \\
\text { Upward Bound program. Approxi- } \\
\text { mately } 90 \text { min }\end{array}$ & $\begin{array}{l}\text { Pressbook: Profiles of experts working } \\
\text { in neural engineering and neuro- } \\
\text { science; external resources to ex- } \\
\text { plore pathways toward a career in } \\
\text { neurotechnology; exploration of col- } \\
\text { lege pathways by exploring depart- } \\
\text { mental websites for undergraduate } \\
\text { majors; } 15 \text { min video on what to do } \\
\text { with a neuroscience degree; infor- } \\
\text { mation on research experience pro- } \\
\text { grams; articles featuring educational } \\
\text { opportunities at the Center for Neu- } \\
\text { rotechnology }\end{array}$ & $\begin{array}{l}\text { Padlet: Participants share some- } \\
\text { thing surprising they discovered } \\
\text { while exploring websites for } \\
\text { undergraduate majors related to } \\
\text { the field of neurotechnology }\end{array}$ \\
\hline $\begin{array}{l}\text { Additional Pro- } \\
\text { gram Ele- } \\
\text { ments }\end{array}$ & \multicolumn{3}{|c|}{$\begin{array}{l}\text { Pressbook: How to read an academic journal article; interactive glossary } \\
\text { Evaluation: Daily attendance surveys; end-of-program evaluation survey } \\
\text { Engagement: Certificate of participation }\end{array}$} \\
\hline
\end{tabular}

members, touring university engineering labs in the departments of bioengineering, electrical engineering, and computer science, and engaging in workshops and activities (e.g., sheep brain dissection lab, college preparation workshop). A major goal of the REACH program was to expose STEM-interested students to the field of neural engineering, including its interdisciplinary nature, and provide them with a window into university-based research. Our design challenge for the online program was to create a set of activities that was similar to the REACH program but delivered virtually to meet multiple criteria and constraints, as outlined below.

\section{NOVEL INITIATIVE}

Due to the cancellation of many other summer STEM programs for high school students, we decided to offer our virtual program for free, and to make it available to all students who applied to the REACH 
TABLE 2. Digital tools used in the virtual REACH program.

Digital tool and

\begin{tabular}{|c|c|c|c|}
\hline purpose & Description & Interactive features & Security and accessibility features \\
\hline \multicolumn{4}{|l|}{ Zoom Meeting } \\
\hline $\begin{array}{l}\text { Live synchronous } \\
\text { activities, includ- } \\
\text { ing presenta- } \\
\text { tions and office } \\
\text { hours }\end{array}$ & $\begin{array}{l}\text { Zoom offers an easy to use, web- } \\
\text { based video conference plat- } \\
\text { form that is familiar to many } \\
\text { students }\end{array}$ & $\begin{array}{l}\text { Interactive features include: screen } \\
\text { share, polls, chat, whiteboard, and } \\
\text { breakout rooms }\end{array}$ & $\begin{array}{l}\text { Security features include meeting } \\
\text { passwords and wait rooms }\end{array}$ \\
\hline \multicolumn{4}{|l|}{ Pressbooks } \\
\hline $\begin{array}{l}\text { Interactive digital } \\
\text { book for asyn- } \\
\text { chronous at- } \\
\text { home learning }\end{array}$ & $\begin{array}{l}\text { This platform allowed us to create } \\
\text { professional-looking digital con- } \\
\text { tent that included embedded } \\
\text { interactive elements }\end{array}$ & $\begin{array}{l}\text { Allows for embedded interactive fea- } \\
\text { tures including: links to external } \\
\text { websites and articles, YouTube vi- } \\
\text { deos, images, and custom-built } \\
\text { interactive quizzes in a variety of } \\
\text { formats }\end{array}$ & $\begin{array}{l}\text { Published Pressbooks can be ac- } \\
\text { cessed through the web, as a PDF to } \\
\text { print, or as an ebook. Pressbooks } \\
\text { are accessible to screen readers } \\
\text { Ensured that closed captioning or } \\
\text { transcripts were available for } \\
\text { embedded videos } \\
\text { Chapters can be password-protected }\end{array}$ \\
\hline \multicolumn{4}{|l|}{ Padlet } \\
\hline $\begin{array}{l}\text { Digital bulletin } \\
\text { board applica- } \\
\text { tion to allow for } \\
\text { participant inter- } \\
\text { action }\end{array}$ & $\begin{array}{l}\text { For each chapter of the digital } \\
\text { book, we included a prompt (in- } \\
\text { cluded in Table 1) and an } \\
\text { embedded link to the daily } \\
\text { Padlet }\end{array}$ & $\begin{array}{l}\text { Padlet allows participants to post con- } \\
\text { tent (text, photo, or video) to the } \\
\text { digital bulletin. This allows partici- } \\
\text { pants to view and interact with each } \\
\text { other's responses }\end{array}$ & $\begin{array}{l}\text { Padlet privacy and security functions } \\
\text { include the ability to: make a board } \\
\text { private or password protected, en- } \\
\text { sure that names are not attributed to } \\
\text { posts, automatically filter obscene } \\
\text { words, and require moderator ap- } \\
\text { proval before submissions are pos- } \\
\text { ted }\end{array}$ \\
\hline
\end{tabular}

program, not just those who were selected for admission to the in-person program before it was cancelled. We also wanted to combine live, synchronous program elements that would allow for community building with asynchronous at-home learning resources that participants could explore throughout the week. Of the 90 students who applied to the original REACH program, 75 students indicated that they were interested in participating in the VRP. Therefore, we needed a program that: (1) could accommodate at least 75 students; (2) could be delivered fully online and accessed by students in their own homes; (3) built community between students and researchers; (4) connected students with challenging scientific and engineering content; and (5) allowed students to opt into the asynchronous at-home learning resources based on their interests and available time.

CNT education staff have extensive experience developing curriculum resources related to neuroscience and neural engineering. ${ }^{1,2}$ We decided to create an innovative program that leveraged existing online learning resources from other organizations packaged with at-home learning resources we would design ourselves. An added strength of our plan was to use our existing connections with affiliated faculty members across engineering departments who we had previously identified as being engaging speakers for precollege audiences.

\section{STRUCTURE OF THE ONLINE PROGRAM}

The VRP is a novel five-day online program that we designed in response to these challenges. VRP will be piloted for the first time in July 2020. Each day of the program will focus on a theme, as described in Table 1. The digital tools we will use are described in Table 2. The VRP consists of two major components: synchronous and asynchronous learning activities.

\section{Synchronous Program Elements}

On the morning of each program day, students will join a Zoom meeting (www.zoom.us) for an approximately $60 \mathrm{~min}$ live synchronous presentation from an affiliated CNT faculty member who is an expert in the area related to the theme of the day. Each guest presenter will also be available on Zoom for approximately $30 \mathrm{~min}$ of online office hours, allowing VRP participants to join them for informal conversations about their research or college and career pathways. All VRP live sessions will be hosted by Dr. Chudler and Ms. Sadie Frady, a high school science teacher who has participated in previous research programs at the CNT. The participation of an experienced teacher brought to the program expertise in distance learning, classroom management, and age-appropriate discourse strategies. 


\section{Asynchronous Program Elements}

A collection of at-home learning resources was curated for VRP participants by Drs. Bergsman and Chudler to explore asynchronously. This will allow participants to study topics as deeply as they want at their own pace, although participants will be encouraged to explore relevant resources prior to the daily Zoom presentations. The at-home learning resources are packaged into an interactive digital book through the use of Pressbooks book production software (www.pressbooks.com). The interactive book is available online at https://uw.pressbooks.pub/yspreac $\mathrm{h} 2020$. One chapter of the book is provided for each of the five days in the program and each chapter contains text, embedded videos, images, links to articles from academic journals and popular press, and activities. Short quizzes are embedded throughout the chapters for participants to assess their own developing knowledge. To build community through shared artifacts, each chapter also directs participants to a daily Padlet (www.padlet.com), a digital bulletin board in which participants can respond to a question by posting text, images, or videos, and can interact by "liking" each other's posts. All content will be reviewed and approved by VRP program hosts before being posted to the Padlet. Additional features in the digital book include tips on how to read academic journal articles and an interactive glossary of terms.

\section{SOFTWARE FOR REMOTE LEARNING AND COMMUNITY BUILDING}

We chose to implement three digital tools for the VRP: Zoom Meeting, Pressbooks, and Padlet (see Table 2). These applications were chosen based on their ease-of-use and familiarity to program managers and participants, device-neutrality, security features (particularly important when program participants are minors), accessibility features, and because they were available at no cost or through subscriptions held by our university. Zoom Meeting (www.zoom.us) will be used for the live synchronous activities, including presentations and office hours. Pressbooks (www.pre ssbooks.com) is the application we used to design the interactive digital book featuring at-home learning resources. Padlet (www.padlet.com) is a digital bulletin board application we will use in coordination with the digital book to increase interactivity among program participants.

\section{CONSIDERATIONS FOR WORKING WITH MINORS IN AN ONLINE ENVIRONMENT}

Working with minors in a fully online program environment presents different challenges than an inperson program. While designing the VRP, we took care to consider issues of privacy, online safety, and liability. For example, we required parental permission using a form provided by our university that specifically outlined risks associated with online programs and digital platforms. We also ensured that all live Zoom meetings will be hosted by a minimum of two staff members who have been approved by our university's Office for Youth Programs to work with minors during in-person programs and online environments. These program hosts will also moderate the chat function. Additional security concerns related to the digital tools are explained in Table 2.

\section{REFLECTION}

As we prepare for the start of the VRP, we reflect on the key literature that informed our approach, the program evaluation plan, and the additional benefits offered by this program.

\section{GUIDING LITERATURE}

The design of the VRP was informed by research findings from the fields of STEM education, engineering education, and the learning sciences. This includes recognizing the "life-wide" learning that occurs both inside and outside of the school system (e.g., athome learning), and the importance of supporting youth's development of practice-based identities as scientists and engineers. ${ }^{3}$ The research literature has demonstrated evidence-based best practices for program design of STEM outreach programs, ${ }^{4,5}$ such as university-based summer bridge programs, afterschool programs, and summer camps, that provide opportunities for youth to be exposed to a variety of STEM career fields, support their college readiness, and prioritize broadening participation in STEM. In addition, the program was designed to provide opportunities for high school students to engage with scientific and engineering practices, as described in A Framework for $K-12$ Science Education, ${ }^{6}$ in which researchers describe the authentic problems they are trying to solve, explain 
their research process and tools, and discuss the human dimensions and ethical implications of the therapies, treatments, and devices they create.

\section{PROGRAM EVALUATION}

The evaluation protocol for the VRP was modified from our previous in-person program to gather data on how well the program provided high school students knowledge of the field of neural engineering and provided basic preparation for college studies in STEM subjects. The evaluation protocol, which will be administered to students on the last day of the program in an online survey by an external evaluator, will include the following components:

1. Assessment questions to measure the participants' attitude towards: (1) their virtual learning environment, (2) their satisfaction of the program including social cohesion among students in the program, and (3) how much support and guidance they felt they received.

2. To measure increases in participants' knowledge, a retrospective pre-test design was applied. Data will be analyzed for means and statistically significant differences and will be compared using a pairedsample t-test. To further delve into student learning, data collected in 2020 will be compared to previous years of the in-person program in order to identify any shifts in knowledge trends.

3. Qualitative and quantitative assessment questions were developed to measure how often participants used the digital book's elements and what was most helpful to support at-home learning.

\section{PARTICIPANT ENGAGEMENT}

After each morning presentation, participants will be directed to complete a short, online survey to monitor their attendance. Participants who attend all five sessions and submit all daily surveys will receive a certificate of completion. An open-ended question on the daily survey will ask participants to share something interesting they learned from the presentation, allowing the program moderators to monitor participants' engagement, developing understandings, and emerging questions.

\section{BENEFITS OF THE PROGRAM ADAPTATION}

Transforming a program to an online format led to some opportunities that have the potential to benefit students after the COVID-19 pandemic. While there was a large investment in time in creating the new program, especially the digital book, the outcome is that the CNT now has a new program format and a novel learning tool that can be leveraged in different ways. We plan to publish the digital book on our website and submit it to online curriculum repositories, making it widely available to high school students and educators. As part of our diversity, equity, and inclusion efforts, continuing to offer the program in future summers will allow our organization to reach a larger audience of students than we can accommodate in an in-person program, and will also allow us to expand our reach to students who are located distant to our own community. The absence of a fee also increases accessibility to this summer learning opportunity for families who cannot afford the tuition-based REACH program, for which we offer a limited number of scholarships. Although the VRP will not generate revenue for our organization, it does allow us to foster connections to a large number of high school students who may be eligible to participate in future programs at the CNT and to introduce them to a new field of study.

Other organizations facing the challenge of adapting in-person programs for pre-college audiences to an online environment may benefit from implementing digital tools for delivering content and fostering participant interaction, carefully considering security and privacy issues related to working with minors in an online environment, and developing a plan for monitoring participant engagement and program evaluation.

\section{ACKNOWLEDGMENTS}

We appreciate the program evaluation support offered by Jill Weber from the Center for Research and Learning. We would like to acknowledge the reviewers of the VRP digital book: Timothy Brown, Sadie Frady, Eran Klein, Chet Moritz, and Rajesh Rao. Special thanks to the presenters of the inaugural VRP session: Rajesh Rao, Chet Moritz, Ishan Dasgupta, and Dave Wolczyk, as well as co-moderator Sadie Frady. We also appreciate the work of Nona Clifton and Janis Wignall in creating the original in-person camp program. 


\section{AUTHOR CONTRIBUTIONS}

All authors contributed to the study conception and design. Material preparation was performed by $\mathrm{KCB}$ and EHC. The first draft of the manuscript was written by $\mathrm{KCB}$ and $\mathrm{EHC}$ added and edited text in subsequent versions of the manuscript. All authors read and approved the final manuscript.

\section{FUNDING}

This study was funded by the National Science Foundation (Grant Number EEC-1028725).

\section{AVAILABILITY OF DATA AND MATERIAL (DATA TRANSPARENCY)}

The digital book that features the asynchronous, athome learning resources is available at https://uw.pre ssbooks.pub/yspreach2020/

\section{CONFLICT OF INTEREST}

The authors declare that they have no conflict of interest.

\section{REFERENCES}

${ }^{1}$ Chudler EH, Bergsman KC. Explain the brain: web sites to help scientists teach neuroscience to the general public. CBE Life Sci Educ. 2014;13:577-83. https://doi.org/10.1187/cbe. 14-08-0136.

${ }^{2}$ Chudler EH, Bergsman KC. Brains-computers-machines: neural engineering in science classrooms. CBE Life Sci Educ. 2016;15:1-7. https://doi.org/10.1187/cbe.15-11-0242.

${ }^{3}$ Bell P, Tzou C, Bricker LA, and Baines AD. Learning in diversities of structures of social practice: accounting for how, why and where people learn science. Hum Dev. 2012;55:269-4.

${ }^{4}$ National Research Council. Learning Science in Informal Environments: people, Places, and Pursuits. The National Academies Press, Washington, DC, 2009.

${ }^{5}$ National Research Council. Surrounded by Science: Learning Science in Informal Environments. Washington, DC: The National Academies Press; 2010. https://doi.org/ 10.17226/12614.

${ }^{6}$ National Research Council. A Framework for K-12 Science Education: Practices, Crosscutting Concepts, and Core Ideas. Committee on Conceptual Framework for the New K-12 Science Education Standards, Board on Science Education, National Research Council. Washington, DC: The National Academies Press; 2012.

Publisher's Note Springer Nature remains neutral with regard to jurisdictional claims in published maps and institutional affiliations. 